\title{
Trust, Connection and Equity: Can Understanding Context Help to Establish Successful Campus Community Gardens?
}

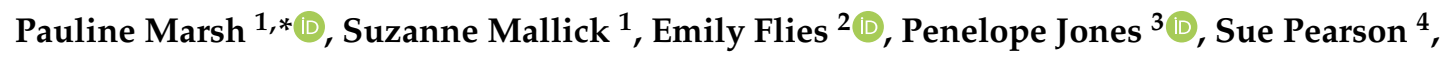 \\ Iain Koolhof ${ }^{4}$, Jason Byrne ${ }^{5}$ and Dave Kendal ${ }^{5}$ (D) \\ 1 Centre for Rural Health, College of Health and Medicine, University of Tasmania, Hobart 7000, Australia; \\ Suzanne.Mallick@utas.edu.au \\ 2 School of Natural Sciences, University of Tasmania, Hobart 7000, Australia; Emily.Flies@utas.edu.au \\ 3 Menzies Institute for Medical Research, University of Tasmania, Hobart 7000, Australia; \\ Penelope.Jones@utas.edu.au \\ 4 School of Medicine, College of Health and Medicine, University of Tasmania, Hobart 7000, Australia; \\ Sue.Pearson@utas.edu.au (S.P.); koolhofi@utas.edu.au (I.K.) \\ 5 School of Geography, Planning and Spatial Sciences, University of Tasmania, Hobart 7000, Australia; \\ Jason.Byrne@utas.edu.au (J.B.); Dave.Kendal@utas.edu.au (D.K.) \\ * Correspondence: Pauline.Marsh@utas.edu.au; Tel.: +61-3-6226-6905
}

Received: 3 September 2020; Accepted: 30 September 2020; Published: 14 October 2020

\begin{abstract}
Campus community gardens (CCGs) can potentially improve student health and wellbeing, mitigate social and ecological problems, and nurture university-community relationships. However, CCGs are located in complex socio-political and ecological settings and many community gardens struggle or fail. However, few studies have assessed the socio-political/ecological context of a garden setting prior to its development to understand the potential barriers and enablers of success. Our study assessed the socio-spatial context of a proposed CCG at a student university accommodation site. We engaged diverse university and community stakeholders through interviews, focus groups and a survey to explore their perceptions of the space generally and the proposed garden specifically. Visual observations and public life surveying were used to determine patterns of behavior. Results confirmed known problems associated with an underutilized site that provides little opportunity for lingering or contact with nature; and unknown barriers, including socially disconnected stakeholders and community distrust of the university. The research also uncovered positive enablers, such as stakeholder appreciation of the social, wellbeing and ecological benefits that a CCG could deliver. Our findings suggest that an in-depth exploration of a proposed garden context can be an important enabler of its success.
\end{abstract}

Keywords: campus community garden; health; socio-spatial connection; trust; sustainability; university students; wellbeing

\section{Introduction}

People's disconnection from Nature is increasingly recognized as harmful to wellbeing and the natural environment. Researchers, activists and policy makers are becoming more interested in interventions that can generate (re)connections between people and nature. Campus community gardens (CCGs), sometimes called student-led food gardens, are an example of such an intervention. As sites of applied learning and research, they are often embedded into curricula, including horticulture, landscape design and sustainability studies [1]. CCG research and teaching benefits are recognized across diverse university departments, including the natural sciences, arts, social sciences and 
geography [2] and CCGs are also playing an important role in university sustainability strategies, as part of the global ecological sustainability agenda. They can foster a heightened sense of responsibility for the environment [3,4] and engage the broader community with issues such as food security [5] energy use, mental health and ecological integrity [6].

For instance, Baker and Bilbro [7] have called for CCGs to be used for more than the utilitarian acquisition and application of student knowledge, suggesting they can shape imagination, build gratitude and enable students to care deeply about place and health. Such gardens can also improve academic success among school children [8], and foster engagement between the broader community and a university when they are established as sites for activities like citizen science and community events [1], social and creative-arts events and other projects [9]. CCGs can bolster connectivity between multiple actors-students, staff and the wider community-and between individuals and natural environments $[4,8,10]$. By participating in gardening, students and community members can experience improved physical and psycho-social wellbeing $[11,12]$ as well as stronger social connections, a deeper sense of place, and a sense of stewardship of the natural environment $[7,12,13]$. This multi-faceted connectivity is at the heart of the wellbeing, socio-spatial and ecological potential of CCGs.

Although planting vegetables together in communal campus sites to improve human and planetary wellbeing sounds simple and attractive, establishing and maintaining a CCG requires considerable planning, coordination and investment of time and energy. For these reasons, despite best intentions, some CCGs can struggle to survive and others fail outright $[3,5,14]$. Yet we know comparatively little about the role that diverse pre-occupancy drivers, barriers and enablers play in CCG success. "Youth" gardening is under-researched [15] and comparatively little is known about university student access to community gardens [9] or indeed about student engagement in green spaces in general [16]. Sometimes, discrepancies exist between institutional aims and processes, and the ideas of students or the wider community - and these differences can be problematic [17]. Perhaps most significantly, university campuses are not simple environments to understand; they are highly complex socio-political and ecological settings [3].

This paper reports the results of a pre-occupancy study of a campus community garden site in Hobart, Tasmania. The study arose from a desire by the authors and university management, who funded the project, to ensure that the CCG was established successfully to deliver positive health, wellbeing and ecological outcomes. By uncovering the complexities of the context for the proposed garden, especially the drivers, barriers and enablers of garden success, we aim to positively influence the design and ongoing management of similar gardens in Australia and internationally. We begin by overviewing the academic literature on campus community gardens. Next, we present the study site and the methods used. We then discuss our findings, highlighting what they reveal about the importance of understanding the broad context. We conclude with a suggested strategy for the effective establishment of CCGs and point to directions for future research on the socio-spatial, wellbeing and ecological benefits of these gardens.

\section{The Role and Function of Campus Community Gardens}

\subsection{CCGs and Physical, Psycho-Social Wellbeing}

Community garden-based research demonstrates positive impacts of community gardens on physical, mental and cognitive health. Benefits are attributed to the core garden constituents of fresh air, social interaction, healthy food, reduced stress and physical exercise [18-23]. Closely associated are benefits owing to nature's ability to facilitate recovery from mental fatigue [24], reduce risk of psychological distress and build healthier cortisol profiles [25]. Oliver Sacks in an essay on hortophilia (the desire to interact with, manage and tend nature that is deeply instilled in humans) suggests that gardens might be "More powerful than medicine" ([26], p. 245). Community gardening, in general, can facilitate wellbeing through social change and improved social equity from the opportunities it affords for civic engagement and political action [11,27-29]. 
Universities, especially those located within cities, can and do play a role in increasing the liveliness of public space. Cilliers et al. [30] note that public spaces that are underutilized can be enlivened through the presence of education institutions, coupled with design that enhances and supports the natural movement and flow of people through urban space. Universities also generate impacts on the environments that surround them-such as increased vehicular traffic, resource consumption, pollution and increased property values [31]. Community gardens located on university campuses (hereafter campus community gardens (CCGs)), can mitigate some of these impacts, as well as conferring a range of benefits on students and the broader community. They thus play an important role in a university's social license to operate [32].

CCGs have been used to deliver onsite, outdoor student wellbeing programs [16] and host creative and social events to facilitate student engagement and maximize the potential for enhanced mental wellbeing. The high risk of mental ill health for the student cohort [33] that is associated with academic stress [34] means they have much to gain from community gardening. Contact with nature among high school students contributes to perceived restoration [35]. Similarly, a study with university students found the presence of green spaces on campus allowed students to recover from cognitive fatigue [16]. CCGs can facilitate social connections for people from minority population groups, including international students, who are more at risk of social isolation [36]. For example, Holt [16] found frequent, active interactions in university green spaces by students led to higher quality of life and increased feelings of happiness. Baur [12] also found improved wellbeing was linked to volunteer engagement in a CCG.

\subsection{CCGs and Connection to Nature}

Built up areas, including university campuses, provide limited options for connecting with nature. In some cases, campus green spaces may be the only accessible natural space for students [12]. Parks, streetscapes, gardens and informal green spaces can help develop and maintain human connections to nature [37] as can community gardens [38]. Not only is this contact important for health, but also student success and completion rates $[8,12]$. Researchers have recommended university management support the establishment and maintenance of natural spaces on campus [12] both for active recreation and for solitude, rest and restoration [16,39]. Myers [38] notes that community gardens are particularly suitable form of urban nature to provide everyday, incidental and fluid contact options. Not only, she argues, can they be created so people can engage with nature in all types of weather conditions, and offer variety in the scale of agriculture or cultivation, they can encourage people to linger and thus enhance the contact experience.

Further, student accommodation sites are generally home to students who are new to a university and potentially to city living too. While demand-driven initiatives at Australian Universities (to increase student numbers from previously under-represented population groups) have increased the numbers of enrolments from people living in rural and remote areas in Australia, overall drop-out rates remain higher for regional or remote students than their urban peers (by age 23) [40]. There are many reasons for incompletions, one being that moving from a rural area into the city necessitates not only a physical transformation, but also a psychological reimagining that can be dogged by self-doubt and uncertainty [41]. Fleming and Grace [40] found some rural students had not seen a university campus or visited a city prior to enrolment. Schultz [42] observed disconnectedness, lack of solitude and intermittent desires to get away from the city among first year university students. CCGs can thus function as a type of therapeutic landscape, as well as having broader sustainability benefits.

\subsection{CCGs and Ecological Sustainability}

Contemporary urban farming and agro-ecology approaches encompass principles of increased nature connectedness and improved ecological sustainability [43]. Community gardens regularly accommodate sustainability practices, such as composting and recycling waste, and have been referred to, eloquently, as sites of embodied sustainability [44]. They contribute to sustainable 
ecological and urban development, generating multiple environmental benefits $[45,46]$ including pro-sustainability attitudes [21] and sustainable food systems-in keeping with the 'Slow City' agenda [47]. Australian and US community gardens and UK allotments are regularly established in communities of low socio-economic status, and often on parcels of 'waste' land that are reclaimed for food production. Some UK researchers argue that small scale allotments can grow sufficient produce to meet daily fruit and vegetable consumption requirements [48]. More recently, community gardening has been recognized as important in mitigating the impacts of climate change [49] and enhancing biodiversity [50].

Universities are well-placed to be leaders in ecological sustainability on local and global levels [51]. Colding and Barthel [52] advocate for universities to actively participate in the global sustainability agenda by implementing measures to reconnect students with natural areas on campus. Reconnection, they argue, can be facilitated through learning opportunities and applied research projects. However, they also suggest retrofitting campuses in line with biophilic design principles to support ecological and socio-spatial connectivity. Duram and Kleine [53] argue similarly, they found that CCGs can increase knowledge of sustainability, as well as institutional sustainability through a range of measures. Campus gardens play a role in Colding and Barthel's [51] connectivity agenda: stakeholder stewardship and the public prominence of the CCG are considered beneficial for developing a stronger sense of place as well as pro-environmental behaviors.

\subsection{Key Factors for CCG Success or Failure}

While there is little academic literature that evaluates the success or failure of CCGs, Duram and Williams [2] suggest key elements for a successful CCG, including: Long term funding, productive gardens, trained workforce, a visible presence, hands-on learning, and links with broader sustainability networks. To this list, we add strong student participation and institutional support [53]. Stephens et al. [51] found a clear organizational structure, close ties to the university curriculum and management, a strategic plan and innovative fundraising events were instrumental in CCG success. Understanding volunteer engagement enablers $[9,54]$ is also important, as is stakeholder support from the broader community and university affiliates. Indirectly, Anderson and colleagues [9] found that personal motivations and regular and interactive communication were key components to securing external financial support.

Stephens et al. [51] have identified the barriers to CCG success as including: Competing priorities and obligations; issues around modes of communication and lack of information; inconvenient/poor timing of the organized activities and perceived lack of opportunities for involvement. CCGs can fail when design is inadequate, people are not engaged and university management is not committed (financially and otherwise) to their success [14]. Other barriers include when student turnover is high, there is a lack of guidance and limited financial resourcing [5] and an overreliance on volunteerism from a transient student community [21]. Universities aspire to be connected with the communities in which they are located, to be 'outward looking' [52] and leaders in sustainability [2]. However, Colding and Barthel [51] suggest that university boards can sometimes function as a barrier to a sustainability agenda, depending on the alignment with broader fiscal, value and educational demands. Increasingly, universities struggle to gain the confidence and trust of the public, and power imbalances between the institutions and community members are common $[55,56]$. CCGs offer one way that universities can improve their social license to operate.

\section{Methods}

This study employed a mixed-methods approach. We characterized the socio-spatial and wellbeing context of the pre-garden site primarily through visual observation and engagement with a range of stakeholders. Through discussion, we sought people's perceptions of the space, their thoughts about a CCG and potential constraints. We gathered input from those most impacted by the planned establishment of a CCG - students, people currently using the public spaces associated with the accommodation facility, the surrounding retail community and gardeners from nearby urban 
community gardens (hereafter, stakeholders). Informed by a critical geography methodology [57] and a desire to understanding, know and experience the world via multiple perspectives a mixed methods design was implemented [58] using semi-structured, in-depth interviews, a focus group, an online survey, public life observation, and video observation. For a full summary of methods and relevant stakeholder codes, see Table 1. Ethics approval was obtained from the Social Science Human Research Ethics Committee at the home institution (Reference H0018320).

Table 1. Study methods with the associated data collection process and relevant stakeholders.

\begin{tabular}{|c|c|c|}
\hline Method & Data Collection Detail & Stakeholders (Number)/Code \\
\hline Interviews & $\begin{array}{l}\text { Semi-structured, in depth, } \\
\text { face-to-face }\end{array}$ & $\begin{array}{l}\text { Local Business employees and owners } \\
\text { (15 sites)/BS }\end{array}$ \\
\hline Interviews & Semi-structured, brief, face-to-face & $\begin{array}{l}\text { Members of the public utilizing the } \\
\text { public outdoor space }(n=20) / \mathrm{PB}\end{array}$ \\
\hline Focus Group & 2-hour semi-structured discussion & $\begin{array}{l}\text { Urban green practitioners and } \\
\text { community gardeners } \\
(n=10) / \mathrm{FG}\end{array}$ \\
\hline Observation & 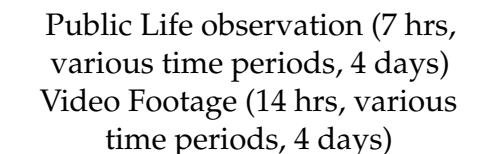 & $\begin{array}{l}\text { Members of the public utilizing the } \\
\text { spaces, including student residents }\end{array}$ \\
\hline Survey & Online & $\begin{array}{l}\text { Local communities, mostly focused on } \\
\text { students residing in UTAS city } \\
\text { accommodation }(n=64)\end{array}$ \\
\hline
\end{tabular}

\section{Site Description}

In 2019, the University of Tasmania (UTAS) commenced planning for a community garden at one of its recently built inner-city student accommodation sites, the Hobart Apartments. UTAS is the single university in Tasmania, an island state with a profile typical of regional areas in Australia: a small population (state population: $\sim 517,000$, spread across cities and regional towns. The primary UTAS campus is located just outside the regional capital city, Hobart (population approximately 250,000) with several satellite campuses in other regional towns), widespread social disadvantage and poor health outcomes. In Tasmania, living in a rural location during Year 12 correlates with decreased chances of ongoing study five year post high school completion [40]. According to the Tasmanian Chamber of Commerce: “Tasmanian's ... greatest challenges and potential still exists in the low levels of education, literacy and health outcomes of our population" [59]. Offsetting this disadvantage is a potential health and wellbeing advantage; regional areas are in close proximity to sometimes extraordinary wilderness and natural environments. The results from Australia's Social Progress Index [60] in 2019 captures this scenario well: for the Health and Wellness category Tasmania ranks seventh of the eight states and territories, while in the Environmental Quality category Tasmania ranks first.

In 2019, UTAS announced its intention to consolidate its southern-based campuses in the city over the next 10-15 years. This intention elicited a mixed response. UTAS staff and students raised concerns about possible negative health and wellbeing repercussions, associated with an anticipated worsening of social and nature disconnections. The broader public were concerned about the increased physical presence of UTAS buildings, staff and students in the city (Figure 1). One high profile UTAS alumnus challenged UTAS to provide "solid proof that each [new] building will be to the benefit and not detriment of Hobartians' daily lives and the amenity of the city" [61].

The Hobart Apartments are located in the Midtown retail precinct of the state's capital, Hobart. It is one of several new student accommodation buildings UTAS established in the city during 2017-19. The UTAS Hobart Apartments site is located on a corner block and extends behind existing heritage shops and buildings. It consists of 430 apartments with a University shop front, a cafe and a car park (with public parking spaces). The Hobart Apartments occupy $12,238 \mathrm{~m}^{2}$, and the outdoor areas are 
a mix of public and student-only spaces, in and around the three wings of residential apartments (Figures 2-5).

The CCG was proposed to extend across all of the outdoor spaces, including the public and private sites.

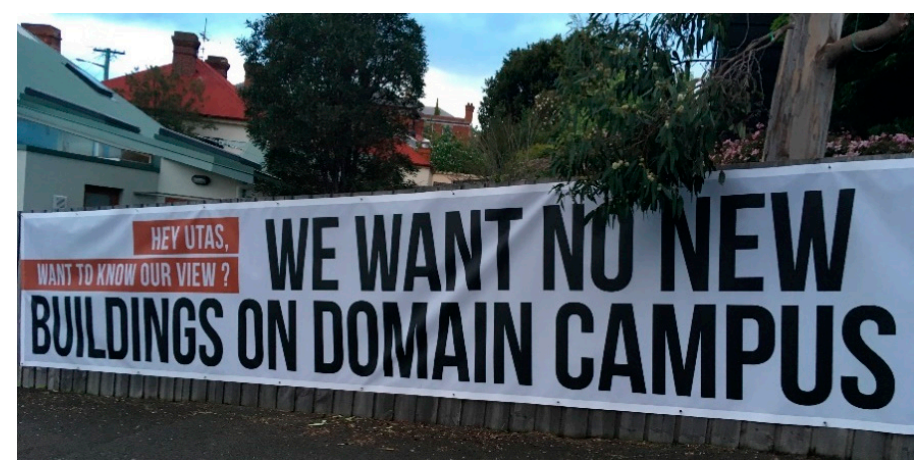

Figure 1. Inner-city residents respond to the Southern Future Strategy announcement.

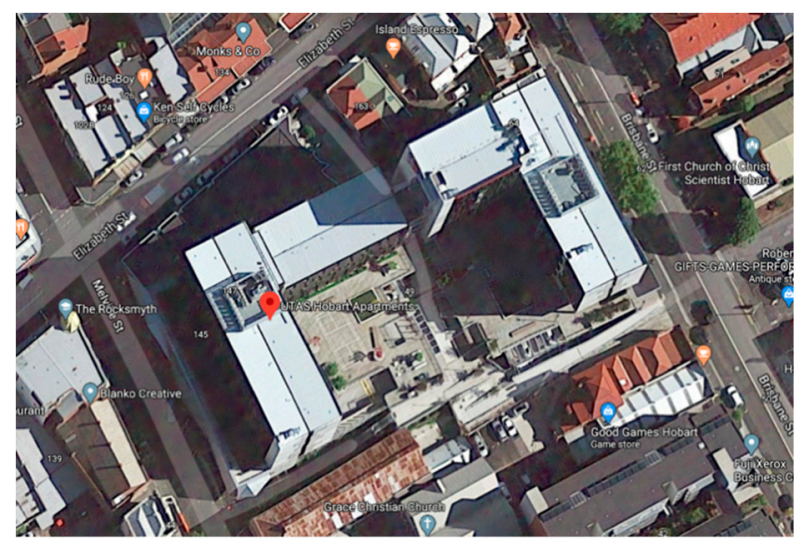

Figure 2. Aerial view of the student apartment complex and proposed garden sites [Google Maps].

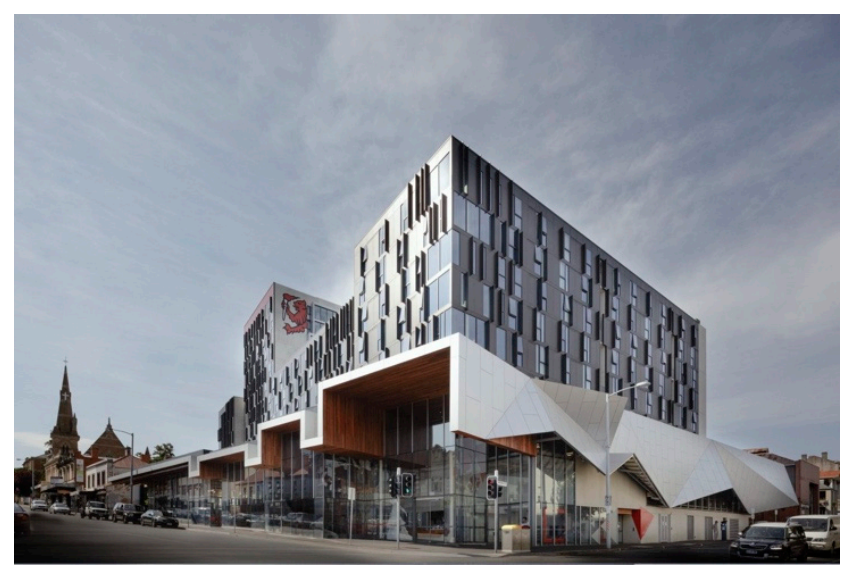

Figure 3. Street view of the apartment complex [Photographer: John Gollings AM]. 


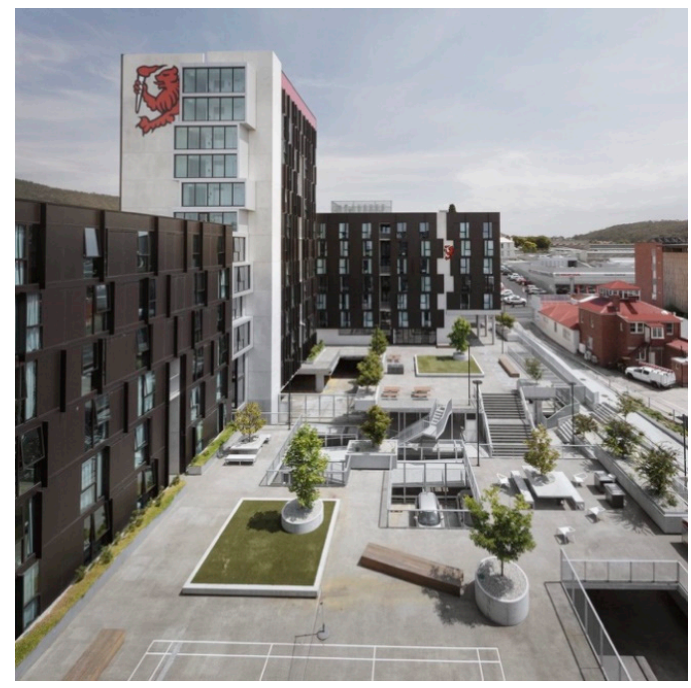

Figure 4. Aerial view of the proposed garden site and existing greenery in private and public areas. [Photographer: John Gollings AM].

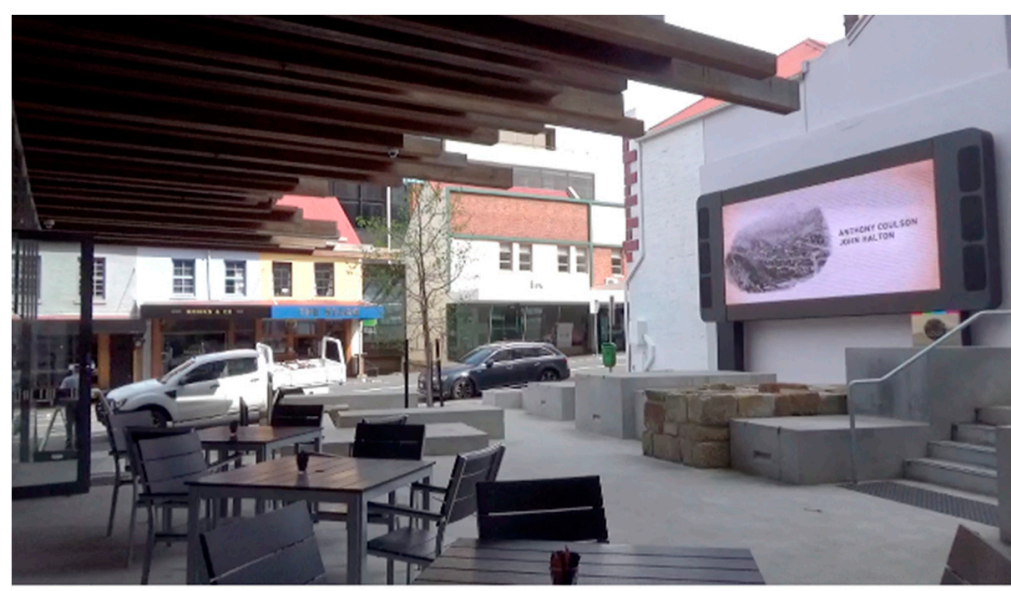

Figure 5. Café exterior, including “The Loop" video installation.

\section{Data Collection}

\subsection{Interviews and Focus Groups}

Local surrounding businesses and people moving through the site were invited to participate in semi-structured interviews. With consent, they were asked for their opinions on: the current use, appeal and function of the site; the health and wellbeing impacts of green spaces and community gardens in general; the proposed UTAS move to the city and ideas for possible usage of the site. A focus group was also held with participants experienced in community gardening, urban farming, or inner-city greening. Through open-ended questions, the focus group participants discussed the potential of a community garden at the site and the associated challenges and benefits. All interviews and the focus group discussion were digitally recorded and transcribed.

\subsection{Site Observation}

Non-participatory on-site observation was also undertaken by researchers at designated intervals to gather visual information about current movement through the space and the activities that people undertook there. Using modified public life survey tools [62] to survey for liveliness, we combined the people moving count and stationary activity mapping to record numbers of people moving through the space and at various times (movement through), as well as the frequency and type of activities 
undertaken (stationary activities). The surveyor followed a regular circuit through the upper and lower sections of the site and the survey sheet captured time, weather and observation notes.

In addition, a video camera was located in two prominent spots, alongside a sign alerting passers-by to the recording, at additional designated times. Data collection took place over a few weeks during early spring at the time of changeable weather. The footage further captured movement of people in and through the space. Combining the upper and lower sites we obtained 7 hours of video footage and 320 minutes of surveying (physical observation) collected over five days at various times of the day during the week and on the weekend (Table 2).

Table 2. Observational Data summary.

\begin{tabular}{|c|c|c|c|c|c|}
\hline Day/Time & $\begin{array}{l}\text { Method/Period of } \\
\text { Observation (min) }\end{array}$ & $\begin{array}{c}\text { Weather } \\
\text { Warm vs. Cool * }\end{array}$ & $\begin{array}{l}\text { Episodes of } \\
\text { Movement } \\
\text { through }(n)\end{array}$ & $\begin{array}{l}\text { Episodes of } \\
\text { Stationary } \\
\text { Activity }(n)\end{array}$ & $\begin{array}{l}\text { Total Episodes } \\
\text { of Public Life ( } n \text { ) }\end{array}$ \\
\hline Thursday 9 a.m. & Researcher/40 & cool & 12 & 0 & 12 \\
\hline Thursday 1 p.m. & Researcher/40 & warm & 17 & 3 & 20 \\
\hline Thursday 4:05 p.m. & Research/40 & cool & 16 & 0 & 16 \\
\hline Thursday 7 p.m. & Researcher/40 & cool & 4 & 0 & 4 \\
\hline Friday 10 a.m. & Video/60 & cool & 39 & 1 & 40 \\
\hline Friday 12 noon & Video/60 & cool & 61 & 7 & 68 \\
\hline Friday 2:45 p.m. & Video/60 & warm & 42 & 4 & 46 \\
\hline Friday 4:20 p.m. & Video/60 & cool & 44 & 2 & 46 \\
\hline Saturday $(1) * 10$ a.m. & Researcher/40 & cool & 17 & 1 & 18 \\
\hline Saturday (1) 12 noon & Researcher/40 & warm & 15 & 1 & 16 \\
\hline Monday 9 a.m. & Video/60 & warm & 37 & 1 & 38 \\
\hline Monday 1 p.m. & Video/60 & warm & 54 & 5 & 59 \\
\hline Monday 3:30 p.m. & Video/60 & warm & 36 & 1 & 37 \\
\hline Saturday (2) 1 p.m. & Researcher/40 & warm & 20 & 3 & 23 \\
\hline Saturday (2) 3 p.m. & Researcher/40 & warm & 2 & 27 & 29 \\
\hline TOTALS & $740 \mathrm{~min}$ & & 416 & 56 & 472 \\
\hline
\end{tabular}

* The Saturday sessions were split over two to accommodate a major sporting event; Spring weather conditions were categorised into two broad descriptors by the researchers on site.

\subsection{Online Questionnaire}

A short online questionnaire was developed to provide some insight into current quality of life, connection to nature and trust in the university by local communities (particularly the student body). Participants were recruited through posts on residential student Facebook groups and posted notices at student accommodation. Movie vouchers were offered as incentive and informed consent was implied by completion of the survey. The survey instrument included several standard psychometric Likert-type scales measuring both wellbeing via the Personal Wellbeing Index $[63,64]$ and connection to nature via the 6-item Nature Relatedness [65]. A scale measuring trust in institutions procedural fairness in engaging the community was adapted from a published scale [66] and separately phrased for students and local community members. Additional data were collected on student enrolment (degree and year of enrolment), aspirations (intention to finish their degree) and basic demographic information. An open-ended question was used to collect additional qualitative data on participants' views on the establishment of a community garden in the city as part of the campus move.

\section{Analysis and Results}

A convergent analysis approach was applied, using the conventions appropriate to each method. In this section we explain the analysis process and present the results for each method.

The interviews focus group data and open-ended survey question were analyzed using reflexive thematic analysis techniques and inductive coding $[67,68]$. Two researchers initially read each of the transcripts independently and assigned relevant codes. The codes were then synthesized through a dialogical process of discussion, reflection and revision. This process generated themes and subthemes which were subsequently discussed, reflected upon and refined by the wider research team. The final four themes pertaining to the potential impacts of the campus community garden were health and 
wellbeing impacts, social connectivity, nature connectedness and Midtown community building (Appendix A).

The observational data and video footage were analyzed through a similar interpretative process involving viewing, coding (patterns of movement, pace, and interactions), reflection and discussion by two researchers until the patterns of human interaction with and within the space were determined. Two key findings are generated by analysis of the observation data. Firstly, there is far greater continuous movement though the space than lingering (Figure 6) and secondly, warmer weather encouraged lingering, but generally activity was intermittent and short in duration (Table 2).

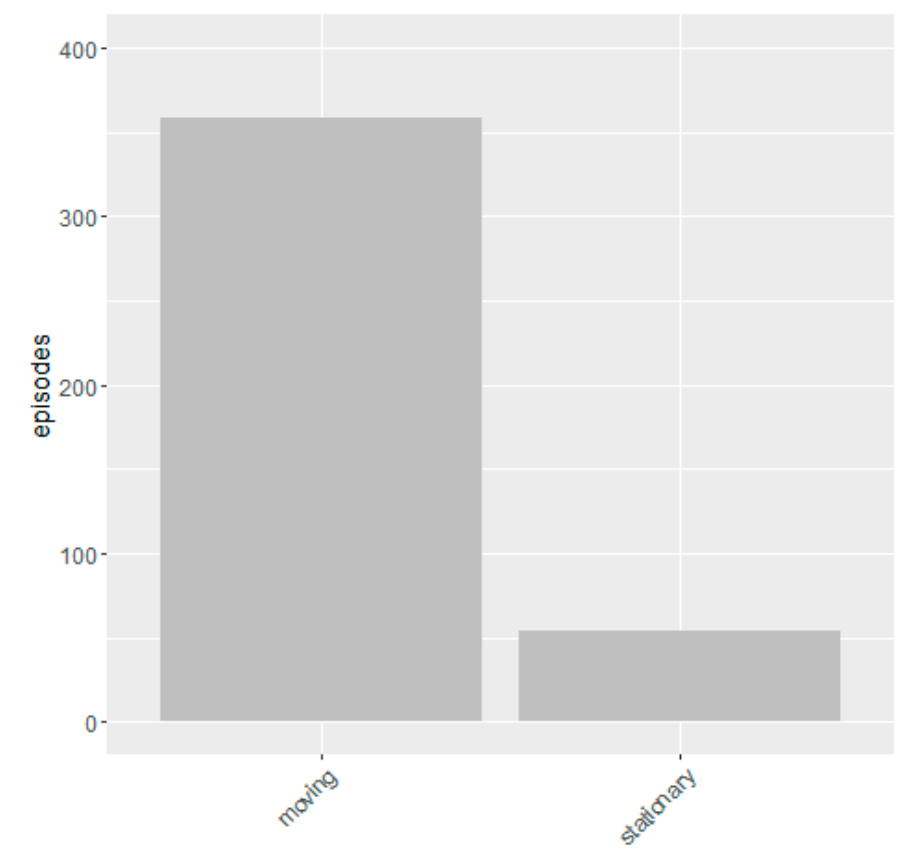

Figure 6. Episodes of movement and stationary activity observed.

The weather during the week of observation was typical of a Tasmanian spring with a dynamic mix of cold weather, intermittent sunshine, cloud cover and wind. Parts of the site were variously in sun and shade as the day passed, and some areas were subject to strong wind depending on the direction. In this regard, patterns of behavior were predictable. When the weather was either 'sunny', 'part sun' or 'warm' episodes of stationary activities increased. In cooler times people stood or sat in the sun, while on sunny days they waited in the shade. In rain and wind, no people sat in the open spaces, and when the undercover areas were in full shade (outside the café) no one sat in them. The greatest number of stationary activities took place on Friday afternoon and Saturday (Table 2) at which time the space was occupied by a group of parkour enthusiasts in which people made the most of the concrete features of the lower space. Other activities comprised such things as eating lunch, talking on the phone and waiting with children (Figure 7). Apart from a couple of students who studied at a table, most of the stationary activities lasted only a few minutes. Despite "the Loop" (see Figure 5 above) running continuously for the $740 \mathrm{~min}$ of observation, only 4 people were observed to stand and watch it for a few minutes.

A total of 64 respondents completed the survey. This included 43 current students ( 23 living at the Hobart Apartments and 14 living at other student residences in Hobart), and 21 community members. Fourteen students identified as being from rural or regional Tasmania before studying, 15 from mainland Australia and six international students. Fifty-nine percent of respondents identified as female, 37 percent as male, and 4 percent as non-binary. For quantitative survey data, we first validated the psychometric properties of the revised trust scales by calculating Cronbach's alpha on the student and community versions of the procedural fairness trust scale. These showed that the scales had a high level of internal validity (standardized Cronbach alpha $=0.97$ and 0.99 respectively). Means and 
95 percent confidence intervals were then calculated for the Personal Wellbeing Index, nature relatedness and trust scales. These were compared with results from previous studies [66,69] plus unpublished data on nature relatedness from a contemporaneous national study of 2000 Australians [70].

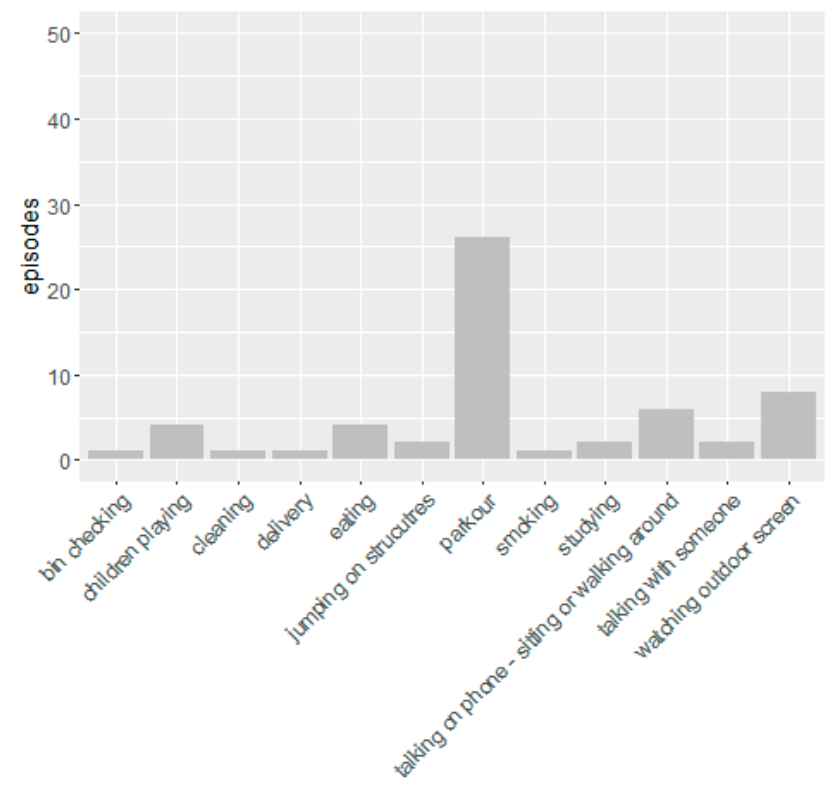

Figure 7. Types of activities observed.

A comparison of average levels of personal wellbeing, nature relatedness and trust with the results of other studies shows that survey respondents had relatively low levels of personal wellbeing and high levels of nature relatedness (Figure 8). Levels of institutional trust were analyzed separately for students and the general community. While the small sample size increased uncertainty (as indicated by the large error bars), there was some indication that levels of trust were relatively low in both the student population and the general community.

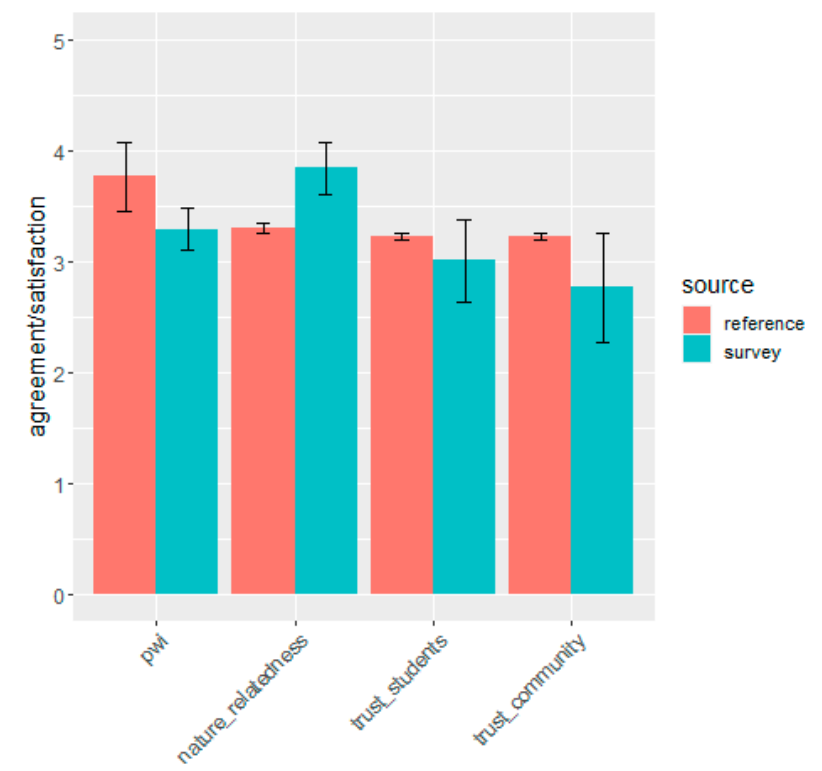

Figure 8. A comparison of respondents Personal Wellbeing Index (pwi), Nature Relatedness, and Trust in the university to engage with (a) students and (b) the local community, compared with reference results from other studies. $95 \%$ confidence intervals are shown. 
Examining each individual Personal Wellbeing domain shows that respondents had lower levels of 'future security', 'feeling part of community', 'achievements in life', 'health' and 'life as a whole' (Figure 9).

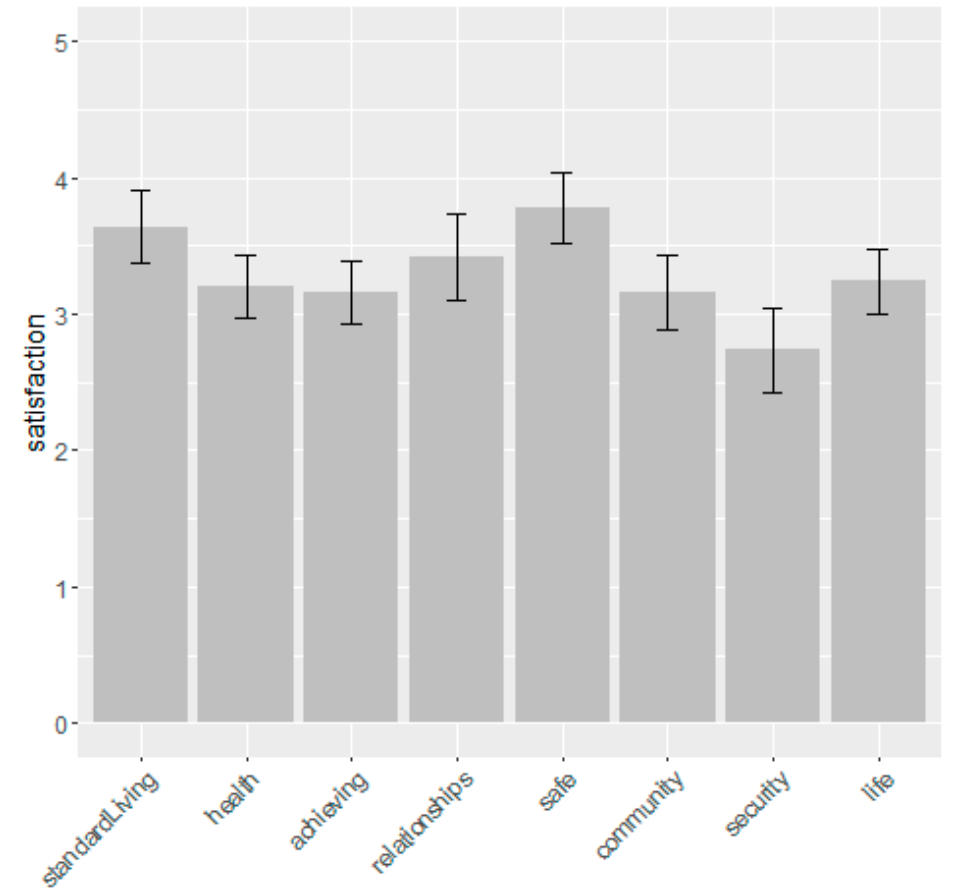

Figure 9. Respondents individual Personal Wellbeing Index scores. 95\% confidence intervals are shown.

In addition to the above, 24 participants provided a brief response to the optional open-ended comments section of the survey. Three broad themes, related to our aim, were generated from our analysis of these: green space, community space and living space.

Critical interpretation of these results provides in-depth insight into the local context for this campus community garden and identifies likely enablers and constrains for its capacity to have positive impacts on people and natural environments. In the following section we discuss what the results collectively reveal about the pre-garden socio-spatial and ecological context and the anticipated constraints for the CCG.

\section{The Pre-Garden Wellbeing, Socio-Spatial and Ecological Context}

\subsection{Health and Wellbeing}

There was widespread acknowledgement of the health and wellbeing benefits of green spaces, nature and gardening across all stakeholders in our research, and people drew upon both personal experience and empirical evidence to make this point. Two factors appeared to augment the perceived importance of the greening intervention in this context: the inner-city location of the site and that the site was for students to live in. Student mental wellbeing was perceived as an important outcome of improving the greenery of the area, and the establishment of a CCG, for many community members. The retailer's prediction of a looming student mental health crisis from disconnection to nature, for example, was expressed in various ways by many others. The importance of mental health as a factor was reinforced by survey respondents reporting relatively low levels of personal wellbeing.

The perception of potential health and wellbeing benefits also extended to the health of the broader community. Access to green spaces for people living and working in a city was seen as desirable because they were calming, especially if away from traffic noise and buildings. Some wanted quiet areas for rest and restoration, others thought the sites should be greened to enable more active recreation. The perceived effects on health may have been emphasized due the research being undertaken at onset 
of spring, when people were appreciating the opportunities to be outdoors in finer weather after a Tasmanian long and dark winter.

However, the pre-garden site was failing to deliver positive health or wellbeing benefits to either students or the community. Students stayed in their rooms, people walked through the site without lingering and many sought out restorative greenery in other areas of the city, or beyond. Stakeholders who grew up, or currently lived, in rural Tasmania did not use the site, or the city in general, as a means of connecting with nature. The results show a need to change the physical structure of the site to enable better contact with nature, as well as to find measures to encourage student and community participation in the site. Despite all of this, the CCG was considered a welcome intervention having the potential to improve psycho-social human health and wellbeing.

\subsection{Aspirations for Social Connectivity}

Most stakeholders-students, public and local traders-were using the site to transit from an adjoining street, the onsite-car park or the student accommodation, further into the city. People were not inclined to linger in the site and regular passers-by confirmed it was often empty. One student described how he had chosen the Hobart Apartments because he thought they would provide 'a community' but felt this had not happened. This social disconnection was in part attributed to the physically unwelcoming site. One person thought the site was a 'memorial' for a tragic event, others were less extreme but expressed a similar sentiment.

There was also a strong desire to use the outdoor space in ways that improved opportunities for social interactions and community building. Some stakeholders saw the UTAS presence in the Midtown region as an opportunity to continue building the vibrancy in the area. One business noted that as the Hobart Apartments site was being built the vacant shops started to fill and several businesses were optimistic about the future plan to consolidate more of UTAS to the city. The community garden was considered to have positive potential to further increase community participation and engagement.

The reality of the unwelcoming space contrasts with the ambitions for the space held by surrounding businesses. Midtown is characterized by small locally owned retail and service outlets, some run by families, who consider themselves the creative and energetic edge of Hobart city. They are enthusiastic place-makers. Although the site was not considered 'activated' or to be engaging for either the community or the students, there was much goodwill toward changing this and towards utilising the space to bring resident students and other community members together. The car park, café area and open spaces were thought good 'enablers' for events, activities and meeting up with people, and people recalled a successful community event held soon after the Hobart Apartments opened.

The Midtown community of traders were committed to revitalizing the city in creative and innovative ways, and felt it was important that students weren't physically or mentally 'separated out', but engaged in this broader trading community. One local organization was already interacting with students and saw enhanced opportunities to work more with UTAS. A CCG has the potential to be consistent with, and complementary to, the Midtown community's sense and vision of place, as well as stakeholder ideas about the value of city greenspace.

\subsection{A Place in the Global Ecological Sustainability Agenda}

When informed about the possibility of a campus community garden on the Hobart Apartments site, students and other stakeholders were enthusiastic about the opportunity it would give them to be engaging in nature and in broader issues of ecological sustainability. Although some participants appreciated the 'industrial', 'modern', or 'concrete-blocks-like-art-installation' appearance of the space, the improvements they suggested were overwhelmingly concerned with additional greening or including natural materials.

Participants valued green spaces and considered access to them to be what made the University of Tasmania unique. This contributed to individual decisions to study at UTAS, as it was thought to provide a relaxing and 'eco-friendly' environment. However, these opinions relate to the existing, 
suburban UTAS Sandy Bay campus, which is surrounded by bushland and has urban green spaces permeating the campus. Participants viewed the move to the city as one that would detract from this appeal and felt there were insufficient green spaces planned and missed opportunities to establish a green "wilderness" in the city. Further, survey respondents had relatively high levels of Nature Relatedness, suggesting a need for opportunities for students and the local community to connect to nature.

The fact that several local traders suggested the university collaborate with them to introduce shared sustainable practices on the site indicates a sense of collective responsibility, beholden to both an inner-city community and a university community. The focus group considered the potential community garden to have educational value for students and community members alike to learn about sustainability measures such as waste management, biodiversity and composting. The possibility that UTAS might steer a collaborative 'hub' for community gardens in the area was encouraged by focus group members. However, some stakeholders suggested there was a need for deliberate strategies to ensure that students connected with nature in the garden, that is, they assumed that students would be disinclined to do this of their own accord. The transient nature of volunteers and students, depending on the time of year, was also raised, as were other commitments on the university calendar such as academic assessment times.

There was strong interest in establishing a CCG as a means of raising awareness of and improving the ecological sustainability of Hobart city and globally. Participants valued connection to wilderness as well as ecological sustainability. Across stakeholder groups people expressed a sense of personal responsibility for addressing climate change and increasing biodiversity. Focus group participants were particularly outspoken on this issue, many of whom are part of a dynamic sustainable community gardening and urban greening movement in Tasmania. They suggested the CCG model have sustainability at its core rather than a focus on large-scale food production which was considered unachievable on the site.

Focus group participants also stressed the importance of planning, sticking to a 'model', and including professional horticultural management and/or a facilitator to ensure the success of a community garden. Implementation of a community garden may require a multi-staged approach, but participants saw an opportunity to make the garden a place for interaction and collaboration from other urban agroecology projects and gardening entities in the city.

\section{Anticipated Constraints}

\subsection{Socio-Spatial Disconnections}

At the time of our pre-occupancy research, the site was not facilitating people's connection to nature or to each other. The site was underutilized on all days and periods of our observation, apart from the visiting parkour crowd on a weekend. Most people were taking a short cut through rather than stopping and spending time; the effect was the creation of outdoor corridors, rather than spaces for socializing or communal recreation. The through movement was in part influenced by weather conditions and cool microclimates, which did not encourage sitting or standing still for long. In rain and wind, no people sat in the open spaces, and when the undercover areas were in full shade (outside the café) no one sat in them. However, these climatic factors were exacerbated by physical factors, such as extensive shade, cold concrete blocks and few wind breaks. People made suggestions that indicate a desire for a more comfortable and restorative outdoor space: chairs, grass to lie on, a children's slide, bean bags, couches, a fountain or water feature.

One major barrier to the use of the outdoor areas was that people were confused as to whether it was public or private space, including the university staff managing the student accommodation site. This was exacerbated by a diversity of stakeholders with different ideas about public/private sites. Concerns about outside persons accessing certain areas on the university campus late at night had negative impacts on survey respondents' sense of security and personal safety. A person who 
was asked to move on from the public BBQ, for example, was homeless at the time and had been cooking dinner. He did not know why the accommodation manager moved him on, but perhaps the manager was unclear about the private/public space delineations and felt the site should be used for other activities, or that a homeless person was not welcome at the student accommodation.

Part of the challenge for place-making and liveliness in spaces where the public and private intersect is meeting these various and varied needs. This is perhaps heightened in a regional island setting with a small population, where historically home spaces and the city center have been separated. Mixing private residences alongside retail outlets is relatively new for Hobart.

\subsection{Distrust}

Although UTAS hopes the planned move to the city creates "a campus that is welcoming to all and that builds community" [71] our results show the university is perceived as irresponsible with money, particularly in light of the broader context of disadvantage in the state. While there was evidence of a historical culture of respect for the university, that has been challenged by more recent decisions and actions in the city. Some raised concerns that the university was catering to international students rather than local Tasmanians. Locally, the actions of UTAS buying property and developing large buildings in the city was interpreted as a display of arrogance and disrespect for community values. There were recollections of broken promises-the university had said they would engage the local community in decisions around use of this space but had not followed through.

Many retail business participants claimed there was little direct engagement between students and retailers. Students rarely visit the Midtown businesses and businesses are not regularly involved in the student accommodation sites. On the whole, there seems to be a social disconnection between UTAS, the student residents and the surrounding business community. Business participants felt it was critical that UTAS engage directly with them in the ongoing development processes at the site. Our survey suggests students and the local community have relatively low levels of trust in UTAS to involve students and the community in decision making.

Trust in the university could best be described as fragile. Although the Hobart Apartments were established under a scheme designed to provide affordable accommodation (the National Rental Affordability Scheme), stakeholders were concerned that the university's continued move into the city would inflate rental and accommodation prices and make inner-city living less affordable. For many, the lack of student patrons and customers was one of several promises that UTAS had made but not delivered on. Other issues related to communication, consultation and participation. People wanted the outdoor spaces to welcome the broader community and not be purely student-focused, and they emphasized the importance of talking with the community and (re)building the relationship with community into the future.

This research reveals deep concerns about UTAS role in perpetuating social and economic inequities in Tasmania. Distrust in the institution will constrain community and student engagement in further initiatives planned by UTAS in this space, including the CCG. It also undermines the University's social license to operate. There was, however, evidence of goodwill towards improving relationship between the Midtown community and the University that may serve as a counterbalance. Creating opportunities in the city were considered important for the greater role this could play in shaping the future of the island.

\subsection{Research Limitations and Future Direction}

The observation methods used in our study cannot reliably reveal whether one episode of movement or activity relates to a single person or multiple visits by the same person (hence the number or a measure of activity are reflected rather than number of individual people utilizing the site). The researcher observation sessions were undertaken by a single researcher moving on foot through the two spaces, in a regular pattern. While the survey responses were consistent with qualitative 
findings, the small sample size of the online survey means that care should be taken in extrapolating results to the whole student body or local community.

Since this research was undertaken, the COVID 19 pandemic has changed the way people engage with public spaces. This, coupled with our results and the work of others, points to future directions for Campus Community Garden based research, exploring the following questions:

- How have public health restrictions impacted CCGs and their capacity to impact positively on health, wellbeing and social connectivity?

- What are the roles and impacts of CCGs in regional areas of low socio-economic status but with easy access to nature?

- What are the variations in experiences of CCGs for discrete student and population groups, such as international students and domestic students?

- What benefits nature and greenspace from the establishment and maintenance of CCGs?

- How do CCGs impact on university and course selection and satisfaction, and how might universities maximize this?

In addition, there is a dearth of research into the long-term sustainability of CCGs, and therefore little knowledge about the factors that directly impact on the success or failure of gardens to have positive impacts.

\section{Conclusion: A Strategy for Creating an Effective Campus Community Garden}

We conclude by proposing a strategy for effective campus community gardens that considers input from existing evidence alongside particularities of a local context (Figure 10). Our aim is not to suggest there is a one-size-fits-all model for successful CCGs, but rather to provide a guide for creating CCGs so that they can best achieve their manifold functions: providing an educational, social and community hub that connects people with each other and with nature; improving physical and psycho-social health and wellbeing; enhancing ecological sustainability; driving social equity in regions of disadvantage; and restoring trust between universities and the communities in which they are located.

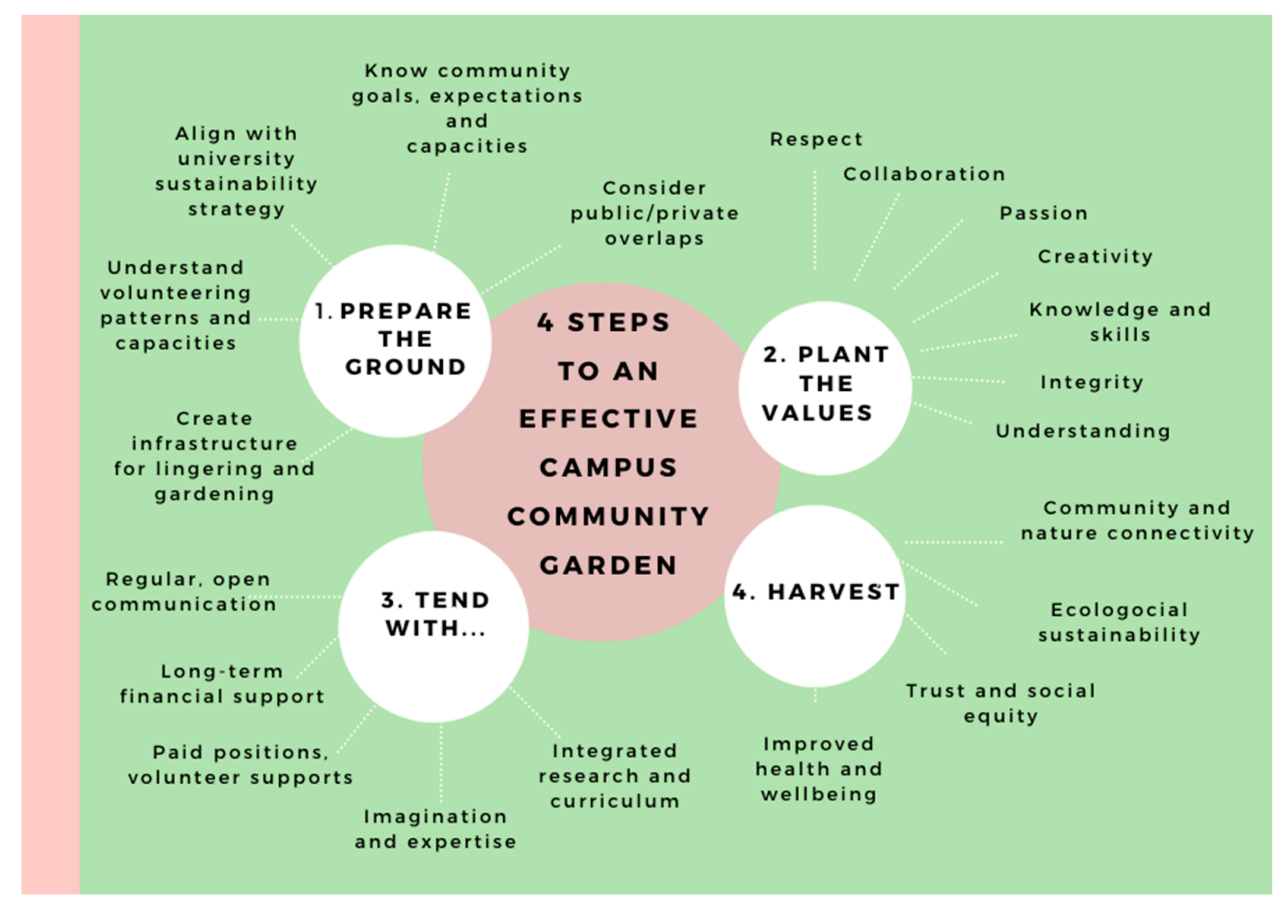

Figure 10. Four steps to an effective campus community garden. 
This research demonstrates the value of gaining an in-depth understanding of a pre-garden context before a campus community garden is established. Without this understanding, potential significant barriers and enablers will go unnoticed, and opportunities to ensure the garden is successful and as impactful as possible can be missed.

Author Contributions: Author contributions are as follows. Conceptualization, P.M., E.F., P.J., and D.K.; methodology, P.M., E.F., P.J., D.K., S.M., S.P.; validation, D.K., S.P., and I.K.; formal analysis, P.M., S.M., D.K., S.P., and I.K.; investigation, P.M., S.M., D.K., and S.P.; writing—original draft preparation, P.M., S.M., and D.K.; writing —review and editing, E.F., P.J., S.P. and J.B.; funding acquisition, D.K., P.M., E.F., P.J., and J.B. All authors have read and agreed to the published version of the manuscript.

Funding: This research was funded by the Office of the Vice Chancellor, University of Tasmania.

Acknowledgments: John Gollings photography used with permission from Gollings Photography Pty Ltd., Australia.

Conflicts of Interest: The authors declare no conflict of interest.

\section{Appendix A}

Table A1. Additional qualitative data.

\begin{tabular}{|c|c|c|}
\hline Theme & Subtheme & Participant Voices \\
\hline Health and Wellbeing & $\begin{array}{l}\text { General benefits from } \\
\text { green spaces, nature and } \\
\text { gardening in the city }\end{array}$ & $\begin{array}{l}\text { Basically, I guess, happiness levels improve with } \\
\text { greenery I guess, you get a little break from daily } \\
\text { living and your work life and the greenery just } \\
\text { improves mood. That's just general. I don't know } \\
\text { any research, it's just a general thought. PB6 } \\
\text { I know a little bit about biophilia, and the sense of } \\
\text { elation that you get just being in a green space and } \\
\text { interacting with nature. I have a graphic design } \\
\text { background and so I know a little bit about color } \\
\text { therapy and color psychology and just being in green } \\
\text { spaces is so good for calming people and I think } \\
\text { that's why we seek it } \\
\text { Just the first days we were able to get outside and } \\
\text { play in our own garden or go to aas well. PB2 park, } \\
\text { just the relief and the de-stress of being in an outdoor } \\
\text { space, with trees and flowers and sunshine. } \\
\text { An instant mood booster. And I guess a lot of people } \\
\text { who work in offices would feel that intense feeling of } \\
\text { boxed in and would like to get out of the office and } \\
\text { get some sun and find a spot to sit. And there are not } \\
\text { that many spaces in the city where you } \\
\text { can do that. BS13 } \\
\text { So I was using it as a bit of a health and wellbeing } \\
\text { space. We've been going through a bit of a stressful } \\
\text { time as we have re-structured and I just wanted to } \\
\text { step out of the building and get some fresh air on a } \\
\text { busy and chaotic day and I grabbed a colleague and } \\
\text { it was I think that day when it was really nice and } \\
\text { warm. And I said let's just get out across the road } \\
\text { and get some fresh air, and we'll sit out and have our } \\
\text { catch up chat out there. So I would really value the } \\
\text { use of that space and would be very keen to } \\
\text { encourage the rest of my staff here to do exactly that } \\
\text { for those purposes. You know, I mean we sit around } \\
\text { in the lunchroom inside but I think there is nothing } \\
\text { better than getting some fresh air and getting out. } \\
\text { So I hope that open space would be preserved and } \\
\text { hopefully improved in some way as well. BS8 }\end{array}$ \\
\hline
\end{tabular}


Table A1. Cont.

\begin{tabular}{|c|c|c|}
\hline Theme & Subtheme & Participant Voices \\
\hline & $\begin{array}{l}\text { Specific student mental } \\
\text { health needs }\end{array}$ & $\begin{array}{l}\text { If you have } 400 \text { students in there that, like aren't } \\
\text { leaving their room, then you have a massive issue like } \\
\text { depression coming at you. If it's not happening already, } \\
\text { in a year or two it is going to. And that's just from } \\
\text { people being isolated, well self-isolating, 'cos they have } \\
\text { nothing else to do apart from look at a screen. Then } \\
\text { again, you come outside and there is a giant fucking } \\
\text { screen ... I can sit in this window and watch maybe } 25 \\
\text { people leave that building a day. And there is like } 440 \text { of } \\
\text { them in there. It's pretty poor. BS1 } \\
\text { I mean, we need them, we need these green spaces ... } \\
\text { 'Cos we all live in concrete jungles now. And especially } \\
\text { for students, 'cos I know a lot of them prefer to stay in } \\
\text { their room, and not go out. For green spaces for } \\
\text { apartments and stuff, it's really important if they are } \\
\text { done well and it's not just an afterthought. If they are } \\
\text { planned out in such a way as to give students more of } \\
\text { an incentive to go outside, and I think that's key to their } \\
\text { mental health. BS10 }\end{array}$ \\
\hline
\end{tabular}

I thought it looked cool ... and I thought it would be good to have community, and to be honest there isn't much of a community here, but good to have a community around me and be a lot better for studying. PB16

I don't think we've had any students in here. I have asked everybody in the block and they are not getting them. BS14

You have a building full of people there who are on

Social disconnection screens all day, and you put a big screen outside? ... Apart from the fact that you have a whole heap of kids in the building who are probably shy anyway. And they are not going to go outside and make their own fun unless it's in their own group, and there is no space for them to do that. BS1

That's another part of living in a city, it can be quite lonely. Yeah so being able to meet people without having to seek people, we all know the dangers of meeting people online. So maybe we need to encourage and facilitate people meeting in real life. BS13

Social Connectivity
Well most of the time when I come through there is no one here. It is very vacant and empty. The café doesn't seem to be, you know it's all very quiet. It surprises me when there is so much accommodation that there are not more people around. PB18

I almost never see anybody here ... I've seen people like one or two times, but not usually anyone. PB9

For me I have been there a few times, have eaten lunch there a few times 'cos we don't have an outdoor space. For me it feels a little bit strange being only the person probably in that space, 'cos no one seems to visit and then it seems like, there are all these windows, feels strange as people looking down at me. You are not sure if there are 20 people just watching me eating my lunch. FG9

Yeah it is pretty quiet here. Except where you have the skateboarders come. And that's probably fine. Yes, I think it's fine. PB17

We do use that one up the back with the flat green, if it's sunny or for events. And this is more for smoking I guess ... I think initially, when they put this up it was to have games but it's just a waste really. PB16

I mean to me it is just a waste of space, I'm sorry, but it is just a waste of space at the moment. BS11 
Table A1. Cont.

\begin{tabular}{|c|c|c|}
\hline Theme & Subtheme & Participant Voices \\
\hline & Transience & $\begin{array}{l}\text { I mean I walk past here everyday but stopping and } \\
\text { using it, I would say probably only a couple of times } \\
\text { a month. PB13 } \\
\text { I never see anybody stopping here or lingering here. } \\
\text { I did see on fellow come out and have a cigarette, } \\
\text { but that's the only person I've ever seen. PB11 }\end{array}$ \\
\hline & $\begin{array}{l}\text { Spatial constraints for } \\
\text { social connection }\end{array}$ & $\begin{array}{l}\text { The biggest downfall is that there is not a whole lot of } \\
\text { sun in the site. Like it's great, it's good to have a little } \\
\text { space off the street, there's stuff for people to interact } \\
\text { with but in the cool months of the year it's too cold } \\
\text { for people to hang around in. I think in the } \\
\text { summertime it will be really nice, 'cos it will be a bit } \\
\text { shady and people can sit and hang out. It would be } \\
\text { good I suppose if there was more interaction inside } \\
\text { and outside. PB1 } \\
\text { I wouldn't think of it as somewhere to go and sit } \\
\text { down, I would just like walk past it. I wouldn't even } \\
\text { look at it, it kinds looks a bit boring. I know they } \\
\text { have that big TV there but it is facing that way and so } \\
\text { it doesn't really have much use, unless you were } \\
\text { going to that café over there. I don't know, it just } \\
\text { seems like it doesn't have much of a use. BS7 } \\
\text { If it had a small lawn there it could be quite stunning } \\
\text { I reckon ... one thing that came up with everyone, } \\
\text { we want more trees, we want more green where we } \\
\text { can come and sit with the dog. BS13 } \\
\text { If there was a little bit more greenery around it I } \\
\text { think it would be a lot more inviting. BS17 } \\
\text { But it's not particularly somewhere you would come } \\
\text { and sit, in this area. If it had much more green stuff, } \\
\text { you'd be inclined to come and sit... It's not a place } \\
\text { where you would hang out for a long time. It's kind of } \\
\text { a meeting place but you would move on from here. PB2 }\end{array}$ \\
\hline & $\begin{array}{l}\text { Confusion over } \\
\text { public/private use }\end{array}$ & $\begin{array}{l}\text { I thought it might just be for the people that live in } \\
\text { these apartments just to come down and have a bit of } \\
\text { fresh air. PB11 } \\
\text { Yeah. So when we would come in to use the BBQ, } \\
\text { one [site staff] he was cool. He was like, 'can you try } \\
\text { to clean the plate', and I was like 'you've got people } \\
\text { here to do that'. And so you might be right eh, that it's } \\
\text { public 'cos you've got people to clean the plate. } \\
\text { And when the [different site staff member] came out } \\
\text { he circled me and said something like, 'these aren't for } \\
\text { public use, it's for students only'. I'm like, 'mate I am } \\
\text { just cooking my chicken and then I will leave'. PB8 } \\
\text { I didn't know that café area was for public use. I had } \\
\text { no idea about that. Until you just told me. And the } \\
\text { same with that back area 'cos I thought it was all very } \\
\text { inclusive to the residents ... And I mean, most of my } \\
\text { friends [student residents] they like to get out of } \\
\text { there and go other places, and so we catch up other } \\
\text { places. I don't know, it's just never been something I } \\
\text { would go and do. BS10 }\end{array}$ \\
\hline
\end{tabular}


Table A1. Cont.

\begin{tabular}{|c|c|c|}
\hline Theme & Subtheme & Participant Voices \\
\hline & $\begin{array}{l}\text { Potential for the site to } \\
\text { connect people to } \\
\text { each other }\end{array}$ & $\begin{array}{l}\text { There's plenty of area out the back for the students } \\
\text { and the kids to do something, you could have a } \\
\text { basketball court out there or something. } \\
\text { Something they want. Kids who live up in the hills or } \\
\text { whatever ... can come down and still play basketball } \\
\text { and interact. And it gets the [international students] } \\
\text { interacting with the locals and stuff like that. BS12 } \\
\text { Like it's a really nice open space. We had the big } \\
\text { party there, where we all had stalls, and music } \\
\text { playing, and bands there. It was really nice. } \\
\text { That's the big open space that comes off the } \\
\text { communal kitchen and common area? Yeah. Well I } \\
\text { mean there is so much you could do up there. BS13 } \\
\text { And it's good we [can] share the space with friends } \\
\text { from the community. I like it. PB3 } \\
\text { You could host regular events. You could have } \\
\text { community yoga. It not all about the infrastructure, } \\
\text { it's about how you activate the space. It's what you } \\
\text { use it for. You could have laughing groups. Or like I } \\
\text { said community yoga. All you need is a roster of } \\
\text { people to be the instructor. Or community exercise. } \\
\text { Or relaxation. BS13 } \\
\text { And back to your community garden idea, that's } \\
\text { incredibly exciting. It would be amazing here for the } \\
\text { students to establish that community, you know, } \\
\text { where they are living, and some of them might be } \\
\text { from overseas and might not necessarily have like a } \\
\text { community of their own. So it would be nice to have } \\
\text { that interaction with people ... Especially if local } \\
\text { cafés get behind it then they could reap the benefits of } \\
\text { it. And grow stuff, and potentially selling it, or using it } \\
\text { in their cafés and reaping the benefits of it. PB2 }\end{array}$ \\
\hline
\end{tabular}

And it is really hard to rationalize what it means to connect with nature. But you notice the effect it has, and in the city, there are very few opportunities to

develop an active relationship with nature ... Instead of just having this conceptual connection to nature, having a physical sensory connection with it. Desire to connect And so, I think community gardens and spaces like Nature Connectedness this can help people form an active relationship with nature. Which is missing from the city environment. FG5

I love a good garden. I am for gardens. That would be great. I would be very interested. PB10

Like I grew up out in the country and so I got a lot of
it. If I lived in the city I don't know what kind of
green spaces I would use, 'cos I have never had to
kind of go and seek them out. To get my fix. PB1
[Some people] have never grown anything,
they don't know how you do things, they don't have
the knowledge. They don't even know what we have
got growing there or what to do with it. FG7


Table A1. Cont.

\begin{tabular}{|c|c|c|}
\hline Theme & Subtheme & Participant Voices \\
\hline \multirow[t]{4}{*}{$\begin{array}{l}\text { Midtown-UTas } \\
\text { community building }\end{array}$} & Food Production & $\begin{array}{l}\text { So perhaps if you think of it more as, how can you } \\
\text { make it a welcoming space for community activity } \\
\text { rather than how can we make it a food production } \\
\text { space, 'cos in terms of food production it is probably } \\
\text { not really an ideal site. FG4 } \\
\text { To get it to work as a gardening space, it would need } \\
\text { to address the wind factor 'cos it is a bit of a wind } \\
\text { tunnel through there and watering issues and you } \\
\text { know, the sunlight issues. So it is really quite } \\
\text { challenging and I don't know that there is that much } \\
\text { space there to actually have a garden for a lot of } \\
\text { people. FG7 } \\
\text { And it is fantastic to have a number of different } \\
\text { elements as well, not just veggie beds. Like you can } \\
\text { have composting and bees, and not chickens at this } \\
\text { space by the sounds of it, but yeah. FG5 }\end{array}$ \\
\hline & $\begin{array}{l}\text { Managing a successful } \\
\text { community garden }\end{array}$ & $\begin{array}{l}\text { From my experience ... you need to have someone } \\
\text { managing it and you need to have that person } \\
\text { coordinating volunteers, and if you can get that team } \\
\text { of volunteers engaged, then it really is a special thing } \\
\ldots \text { if everyone is engaged with the whole garden, } \\
\text { and they work within the whole garden, it really } \\
\text { works very well. I have about } 15 \text { active volunteers at } \\
\text { the moment and a waiting list, and it really does } \\
\text { work well. But it has taken five years to develop that } \\
\text { model. And people come and go. But you have to } \\
\text { have that engagement with the people that want to } \\
\text { be engaged. FG3 } \\
\text { So I do think, whatever system you go to that is a } \\
\text { critical point that, in terms of horticultural system is } \\
\text { it designed for water efficiency and composting and } \\
\text { basically being able to manage all those logistical } \\
\text { elements... it's a challenging environment here and } \\
\text { city environments you need your horticulture all } \\
\text { lined up to make it work, because in any community } \\
\text { scenario if people have a failure I find they are } \\
\text { discouraged very quickly. FG6 }\end{array}$ \\
\hline & $\begin{array}{l}\text { Global environmental } \\
\text { sustainability }\end{array}$ & $\begin{array}{l}\text { It is so essential for our connection to the world and } \\
\text { it also ties into this broader context of ecological } \\
\text { crisis. And if we don't really have a connection to } \\
\text { nature then we are not really going to make the } \\
\text { changes that we need in this time. FG5 } \\
\text { Well the composting, so if you are educating } \\
\text { everyone who lives in the building that you have a } \\
\text { bin for food waste and that bin goes down to the } \\
\text { composting machine downstairs and then gets used } \\
\text { in the garden then. And it is sort of drawing people's } \\
\text { interest into it. FG9 } \\
\text { It's a lot about the satisfaction, education, } \\
\text { and knowledge, and bringing your kitchen scraps } \\
\text { instead of putting them in the bin and knowing they } \\
\text { are, instead of going into landfill, you've got that } \\
\text { input of being able to act at that local level and being } \\
\text { able to do something on a local level. FG6 }\end{array}$ \\
\hline & $\begin{array}{l}\text { The Midtown } \\
\text { community profile }\end{array}$ & $\begin{array}{l}\text { 'Cos our business is so much about community. } \\
\text { Our customers come to us, our regulars do, come as } \\
\text { much for our product as they do for us, it's a family } \\
\text { business, the personality of our staff, the chats we } \\
\text { have over our coffee rushes. We exchange } \\
\text { information on a regular basis with the public. Like I } \\
\text { organized, with some of the other business owners a } \\
\text { street party out here earlier this year. And that was } \\
\text { basically taking away the parking spaces, } \\
\text { having extra seating, live music, and just a bunch of } \\
\text { hay bales, and turned a few kegs into tables as } \\
\text { well. And it was an awesome day, it worked } \\
\text { really well. BS13 }\end{array}$ \\
\hline
\end{tabular}


Table A1. Cont.

\begin{tabular}{|c|c|c|}
\hline Theme & Subtheme & Participant Voices \\
\hline & $\begin{array}{c}\text { Previous } \\
\text { mis/communication and } \\
\text { current mis/trust }\end{array}$ & $\begin{array}{l}\text { It was put into concept, we were excited by what the } \\
\text { original drawings were which had community space, } \\
\text { green space and useable space by the public. But it } \\
\text { kinda didn't eventuate like that. BS13 } \\
\text { I think for most people, who were along here before } \\
\text { the building was started, is a totally different product } \\
\text { to what we were told it was going to be. It's hard } \\
\text { now to back track and have these discussions 'cos it's } \\
\text { built. We were told there was going to bring a lot of } \\
\text { retail along here, to this area. If anything it is worse. } \\
\text { And look I might sound like I'm coming across a bit } \\
\text { frustrated, 'cos I am frustrated. 'Cos look it was } \\
\text { nothing like what, so before they even put the first } \\
\text { hole in the ground they said they would be having } \\
\text { monthly meetings to see that everybody was happy. } \\
\text { Well not one of those meetings happened. Like so } \\
\text { much went on that was like bullshit really. BS12 } \\
\text { UTas are taking these buildings which are 70s or } 80 \text { s } \\
\text { buildings and instead of spending some money and } \\
\text { making it look good on the outside, they are just } \\
\text { taking them and putting a UTas sticker on them and } \\
\text { filling them with students ... It's like, 'come on guys, } \\
\text { you are spending millions on everything else, apart } \\
\text { from the students you are trying to cater for'. BS1 } \\
\text { We didn't have the best experience when this was, } \\
\text { when the building was in process of being built here. } \\
\text { A bit more communication, consultation. I mean they } \\
\text { were pretty good, but perhaps could have been } \\
\text { better... but to have the huge sort of building } \\
\text { towering over us. BS11 }\end{array}$ \\
\hline
\end{tabular}

We have to look after the community as well, I think a lot of people's opinions on UTas are very jaded at the moment. And I think to work with the community to establish relationships and to welcome the community into those spaces, as well, so that it is not $100 \%$ student focused. I guess in a sense without sounding silly, that people don't feel left out.

That you don't take over the city, which is kinda how it feels at the moment. BS13

The city is not just all about the university. There is a lot of stuff that has to be considered. BS12

I am very disappointed ... I know [UTas is] catering to international students who are used to living in high rises but I think they would appreciate the open

Opinions on UTas moving into the city space that is down there at the Uni at the moment. Sport is important to the university and they have the grounds down there. And to me I just think it is changing the fabric of what the city is. I think they should stay and renovate down there. That's my feeling. PB18

So this is a great location in terms of increasing our interaction with the university in formal ways, but also the staff and student body. We have a large number of students that come in and get involved in [our] activities and volunteer activities. [We have an] internationally recognized brand. People know it from their own country and we draw on that lived experience, we work a lot in migration and asylum seekers. But we also generally have people that come in and help us tell our stories and collect our stories and get involved in all sorts of rich ways. BS8 
Table A1. Cont.

\begin{tabular}{|c|c|c|}
\hline Theme & Subtheme & Participant Voices \\
\hline & $\begin{array}{l}\text { UTas and Social } \\
\text { inequities }\end{array}$ & $\begin{array}{l}\text { This idea that they've got too much money for a start, } \\
\text { and I think it's around all the attention on the } \\
\text { homeless people, and people think 'well the } \\
\text { university has all this money', and they think } \\
\text { 'well then why are other people struggling, not just } \\
\text { homeless people but other disadvantaged people?' } \\
\text { I think there is that perception. And that's not the } \\
\text { university's fault at all, it's a much broader issue. } \\
\text { I mean, I just think it's good to have as much } \\
\text { diversity as you can get in a city. But I am not sure } \\
\text { this will do that. Do you know what I mean? I mean, } \\
\text { we are not seeing any real positives out of the } \\
\text { building being there. BSI1 }\end{array}$ \\
\hline & $\begin{array}{c}\text { Good will toward the } \\
\text { CCG idea }\end{array}$ & $\begin{array}{c}\text { You need to make it a hub. So, you want interaction, } \\
\text { and from my point of view ... I can see room for } \\
\text { collaboration. FG3 } \\
\text { It is exactly the word I have been waiting to put out } \\
\text { there, is collaboration. FG1 } \\
\text { There is so much stuff going on in the community } \\
\text { garden space around Hobart and it is all at arm's } \\
\text { length. That is where this is great. FG3 } \\
\text { Yes, if it was something that we were all actively } \\
\text { involved with and encouraged as long-standing } \\
\text { tenants. It's important for us to be engaged with the } \\
\text { community, that's how we keep our business } \\
\text { running. We are total greenies as well as you can see, } \\
\text { all the flowers everywhere. BS13 } \\
\text { And it could be this [community garden] is UTas } \\
\text { trying to engage with the broader community, } \\
\text { and this is asking questions about how universities } \\
\text { function in society and how businesses are involved, } \\
\text { and we are all kind of in the same space and how do } \\
\text { we all kind of coexist in that space is maybe part of } \\
\text { the conversation. FG4 } \\
\text { It should work! There are enough people in there for } \\
\text { that tiny space to work as a spring, summer, autumn, } \\
\text { that people are going to say, 'hey I'm going to take } \\
\text { my stuff that I have to read outside'. BS1 }\end{array}$ \\
\hline
\end{tabular}

\section{References}

1. Scoggins, H.L. University Garden Stakeholders: Student, Industry, and Community Connections. HortTechnology 2010, 20, 528-529. [CrossRef]

2. Duram, L.A.; Williams, L.L. Growing a student organic garden within the context of university sustainability initiatives. Int. J. Sustain. High. Educ. 2015, 16, 3-15. [CrossRef]

3. Laycock Pedersen, R.; Robinson, Z.P. Reviewing University Community Gardens for Sustainability: Taking stock, comparisons with urban community gardens and mapping research opportunities. Local Environ. 2018, 23, 652-671. [CrossRef]

4. Hoover, B.M. The Limited Campus Garden: A Response to "Putting Down Roots: Why Universities Need Gardens". Christ. Sch. Rev. 2017, 46, 385-389.

5. Ullevig, S.L.; Vasquez, L.L.; Ratcliffe, L.G.; Oswalt, S.B.; Lee, N.; Lobitz, C.A. Establishing a campus garden and food pantry to address food insecurity: Lessons learned. J. Am. Coll. Health 2020, 9, 1-5. [CrossRef]

6. Guitart, D.; Pickering, C.; Byrne, J. Past results and future directions in urban community gardens research. Urban For. Urban Green. 2012, 11, 364-373. [CrossRef]

7. Bilbro, J.; Baker, J.R. Putting down roots: Why universities need gardens. In Christian Faith and University Life; Scales, T.L., Howell, J.L., Eds.; Palgrave Macmillan, Cham: New York, NY, USA, 2016; Volume 45, pp. 51-72.

8. Cupples, C.C.; Finewood, M.H. Benefits of College Farms \& Gardens: Gardens and farms on campus boost student health and strengthen academic programs. Today's Dietit. 2018, 20, 20-24. 
9. Anderson, C.; Maher, J.; Wright, H. Building sustainable university-based community gardens: Volunteer perceptions of enablers and barriers to engagement and benefits received from volunteering in the Moving Feast. Cogent Soc. Sci. 2018, 4, 1-19. [CrossRef]

10. Ives, C.D.; Abson, D.J.; von Wehrden, H.; Dorninger, C.; Klaniecki, K.; Fischer, J. Reconnecting with nature for sustainability. Sustain. Sci. 2018, 13, 1389-1397. [CrossRef]

11. Guerlain, M.A.; Campbell, C. From Sanctuaries to Prefigurative Social Change: Creating Health-Enabling Spaces in East London Community Gardens. J. Soc. Political Psychol. 2016, 4, 220-237. [CrossRef]

12. Baur, J. Campus community gardens and student health: A case study of a campus garden and student well-being. J. Am. Coll. Health 2020, 5, 1-8. [CrossRef] [PubMed]

13. Krasny, M.E.; Delia, J. Natural area stewardship as part of campus sustainability. J. Clean. Prod. 2015, 106, 87-96. [CrossRef]

14. Turner, H.; Jacobsen, K. Cultivating a sustainable campus community garden through creation of place. Int. J. Sustain. Educ. 2016, 12, 1-12. [CrossRef]

15. Phibbs, E.; Relf, P. Improving Research on Youth Gardening. HortTechnology 2005, 15, 425-428. [CrossRef]

16. Holt, E.W.; Lombard, Q.K.; Best, N.; Smiley-Smith, S.; Quinn, J.E. Active and Passive Use of Green Space, Health, and Well-Being amongst University Students. Int. J. Environ. Res. Public Health 2019, 16, 424. [CrossRef]

17. Pulkkinen, K.-L.; Staffans, A. The Otaniemi Campus Development and Ecological Sustainability: Perceiving the Environment of a Complex Adaptive System. Int. J. Syst. Soc. 2014, 1, 39-50. [CrossRef]

18. Hartig, T.; Mitchell, R.; de Vries, S.; Frumkin, H. Nature and Health. Annu. Rev. Publ. Health 2014, 35, 207-228. [CrossRef]

19. Jennings, V.; Larson, L.; Yun, J. Advancing Sustainability through Urban Green Space: Cultural Ecosystem Services, Equity, and Social Determinants of Health. Int. J. Environ. Res. Public Health 2016, 13, 196. [CrossRef] [PubMed]

20. Kingsley, J.; Foenander, E.; Bailey, A. "You feel like you're part of something bigger": Exploring motivations for community garden participation in Melbourne, Australia. BMC Public Health 2019, 19, 745. [CrossRef]

21. Laycock Pedersen, R.; Robinson, Z.P.; Surman, E. Understanding Transience and Participation in University Student-Led Food Gardens. Sustainability 2019, 11, 2788. [CrossRef]

22. Marsh, P.; Brennan, S.; Vandenberg, M. 'It's not therapy, it's gardening': Community gardens as sites of comprehensive primary healthcare. Aust. J. Prim. Health 2018, 24, 337-342. [CrossRef] [PubMed]

23. Mitchell, R. Is physical activity in natural environments better for mental health than physical activity in other environments? Soc. Sci. Med. 2013, 91, 130-134. [CrossRef] [PubMed]

24. Stigsdotter, U.K.; Ekholm, O.; Schipperijn, J.; Toftager, M.; Kamper-Jørgensen, F.; Randrup, T.B. Health promoting outdoor environments: Associations between green space, and health, health-related quality of life and stress based on a Danish national representative survey. Scand. J. Public Health 2010, 38, 411-417. [CrossRef] [PubMed]

25. Douglas, O.; Lennon, M.; Scott, M. Green space benefits for health and well-being: A life-course approach for urban planning, design and management. Cities 2017, 66, 53-62. [CrossRef]

26. Sacks, O. Everything in Its Place: First Loves and Last Tales; KNOPF: New York, NY, USA, 2019; pp. $243-247$.

27. Soga, M.; Gaston, K.J.; Yamaura, Y. Gardening is beneficial for health: A meta-analysis. Prev. Med. Rep. 2016, 5, 92-99. [CrossRef]

28. Tan, L.H.; Neo, H. "Community in Bloom": Local participation of community gardens in urban Singapore. Local Environ. 2009, 14, 529-539. [CrossRef]

29. Wakefield, S.; Yeudall, F.; Taron, C.; Reynolds, J.; Skinner, A. Growing urban health: Community gardening in South-East Toronto. Health Promot. Int. 2007, 22, 92-101. [CrossRef]

30. Cilliers, E.; Timmermans, W.; Goorbergh, F.; Slijkhuis, J. Designing public spaces through the lively planning integrative perspective. Environ. Dev. Sustain. 2014, 17, 1367-1380. [CrossRef]

31. Moos, M.; Revington, N.; Wilkin, T.; Andrey, J. The knowledge economy city: Gentrification, studentification and youthification, and their connections to universities. Urban Stud. 2019, 56, 1075-1092. [CrossRef]

32. Chen, C.; Vanclay, F.; Van Dijk, T. How a new university campus affected people in three villages: The dynamic nature of social licence to operate. Impact Assess. Proj. Apprais. 2020, 1-9. [CrossRef]

33. Baik, C.; Larcombe, W.; Brooker, A. How universities can enhance student mental wellbeing: The student perspective. High. Educ. Res. Dev. 2019, 38, 674-687. [CrossRef] 
34. Misra, R.; McKean, M.; West, S.; Russo, T. Academic stress of college students: Comparison of student and faculty perceptions. Coll. Stud. J. 2000, 34, 236-245.

35. Akpinar, A. How is high school greenness related to students' restoration and health? Urban For. Urban Green. 2016, 16, 1-8. [CrossRef]

36. Malberg Dyg, P.; Christensen, S.; Peterson, C.J. Community gardens and wellbeing amongst vulnerable populations: A thematic review. Health Promot. Int. 2020, 35, 790-803. [CrossRef] [PubMed]

37. Lin, B.B.; Fuller, R.A.; Bush, R.; Gaston, K.J.; Shanahan, D.F. Opportunity or Orientation? Who Uses Urban Parks and Why. PLoS ONE 2014, 9, e87422. [CrossRef]

38. Myers, Z. Wildness and Wellbeing: Nature, Neuroscience, and Urban Design; Palgrave MacMillan: Singapore, 2020.

39. Morber, J. Listening to Silence: Why We Must Protect the World's Quiet Places. Yale E360, 30 June 2020.

40. Productivity Commission. The Demand Driven University System: A Mixed report Card; Australian Government: Canberra, Australia, 2019; pp. 1-132.

41. Fleming, M.J.; Grace, D.M. Beyond aspirations: Addressing the unique barriers faced by rural Australian students contemplating university. J. Furth. High. Educ. 2017, 41,351-363. [CrossRef]

42. Schultz, P.F. Upon Entering College: First Semester Experiences of First-Generation, Rural Students from Agricultural Families. Rural Educ. 2004, 26, 48-51.

43. Altieri, M.A.; Nicholls, C.I. Urban Agroecology: Designing biodiverse, productive and resilient city farms. AgroSur 2018, 46, 49-60. [CrossRef]

44. Turner, B. Embodied connections: Sustainability, food systems and community gardens. Local Environ. 2011, 16, 509-522. [CrossRef]

45. Hakkan, L.; Flies, E.; Weinstein, P.; Woodward, A. The impact of green space and biodiversity on health. Front. Ecol. Environ. 2019, 17, 383-390.

46. Tian, Y.; Jim, C.Y.; Wang, H. Assessing the landscape and ecological quality of urban green spaces in a compact city. Landsc. Urban Plan. 2013, 121, 97-108. [CrossRef]

47. Bartłomiejski, R.; Kowalewski, M. Polish Urban Allotment Gardens as 'Slow City' Enclaves. Sustainability 2019, 1, 3228. [CrossRef]

48. Edmondson, J.L.; Cunningham, H.; Densley Tingley, D.O.; Dobson, M.C.; Grafius, D.R.; Leake, J.R.; McHugh, N.; Nickles, J.; Phoenix, G.K.; Ryan, A.J.; et al. The hidden potential of urban horticulture. Nat. Food 2020, 1, 155-159. [CrossRef]

49. Okvat, H.A.; Zautra, A.J. Community gardening: A parsimonious path to individual, community, and environmental resilience. Am. J. Community Psychol. 2011, 47, 374-387. [CrossRef] [PubMed]

50. Lin, B.B.; Philpott, S.M.; Jha, S. The future of urban agriculture and biodiversity-ecosystem services: Challenges and next steps. Basic Appl. Ecol. 2015, 16, 189-201. [CrossRef]

51. Stephens, M.; Gray, M.; Moydell, E.; Paul, J.; Sturman, T.; Hird, A.; Lepper, S.; Prestowitz, C.; Sharber, C.; Steil, A. Endowment Strategies For The University Of Delaware Botanic Gardens. HortTechnology 2006, 41, 495. [CrossRef]

52. Colding, J.; Barthel, S. The role of university campuses in reconnecting humans to the biosphere. Sustainability 2017, 9, 2349. [CrossRef]

53. Duram, L.A.; Klein, S.K. University food gardens: A unifying place for higher education sustainability. Int. J. Innov. Sustain. Dev. 2015, 9, 282-302. [CrossRef]

54. McCabe, T.L.; White, K.M.; Obst, P.L. The Importance of Volunteering Functions to University Students. Aust. J. Volunt. 2007, 12, 50-58.

55. Fisher, R.; Fabricant, M.; Simmons, L. Understanding contemporary university-community connections: Context, practice, and challenges. J. Community Pract. 2004, 12, 13-34. [CrossRef]

56. Johnson, D.R.; Peifer, J.L. How public confidence in higher education varies by social context. Int. J. High. Educ. 2017, 88, 619-644. [CrossRef]

57. Tornaghi, C. Critical Geography of Urban Agriculture. Prog. Hum. Geog. 2014, 38, 551-567. [CrossRef]

58. Creswell, J.W.; Klassen, A.C.; Clark, V.L.P.; Smith, K.C. Best Practices for Mixed Methods Research in the Health Sciences; National Institute of Health: Bethesda, MD, USA, 2011.

59. Richardson, C. Tasmania Report 2019; Tasmanian Chamber of Commerce and Industry: Hobart, Australia, 2019.

60. Amplify. Australian Social Progress Index; Centre for Social Impact: Sydney, Australia, 2019.

61. Baker, E. Man Booker Prize winner Richard Flanagan against University of Tasmania shift. The Mercury, 20 April 2019. 
62. Gehl. Public Life Toolkit 2020. Available online: https://gehlpeople.com/tools/how-to-use-the-public-lifetools/ (accessed on 30 August 2020).

63. International Wellbeing Group. Personal Wellbeing Index, 5th ed.; Australian Centre on Quality of Life: Melbourne, Australia, 2013.

64. Cummins, R.A.; Eckersley, R.; Pallant, J.; van Vugt, J.; Misajon, R. Developing a National Index of Subjective Wellbeing: The Australian Unity Wellbeing Index. Social Indic. Res. 2003, 64, 159-190. [CrossRef]

65. Nisbet, E.K.; Zelenski, J.M.; Murphy, S.A. The Nature Relatedness Scale: Linking Individuals' Connection With Nature to Environmental Concern and Behavior. Environ. Behav. 2009, 41,715-740. [CrossRef]

66. Riley, S.J.; Ford, J.K.; Triezenberg, H.A.; Lederle, P.E. Stakeholder trust in a state wildlife agency. J. Wildl. Manag. 2018, 82, 1528-1535. [CrossRef]

67. Braun, V.; Clarke, V. Reflecting on reflexive thematic analysis. Qual. Res. Sport Exerc. Health 2019, 11, $589-597$. [CrossRef]

68. Bryman, A. Social Research Methods, 5th ed.; Oxford University Press: Oxford, MS, USA, 2016.

69. Capic, T.; Hutchinson, D.; Fuller-Tyszkiewicz, M.; Richardson, B.; Khor, S.; Olsson, C.; Cummins, R.A. Australian Unity Wellbeing Index:-Report 34.0-The Wellbeing of Australians: Financial Wellbeing; Australian Centre on Quality of Life, School of Psychology, Deakin University: Melbourne, Australia, 2017.

70. Kendal, D.; Ordonez, C.; Davern, M. University of Tasmania, Hobart, Australia. Unpublished work. 2020.

71. University of Tasmania. Southern Future 2020. Available online: https://www.utas.edu.au/southern-future (accessed on 30 August 2020).

Publisher's Note: MDPI stays neutral with regard to jurisdictional claims in published maps and institutional affiliations.

(C) 2020 by the authors. Licensee MDPI, Basel, Switzerland. This article is an open access article distributed under the terms and conditions of the Creative Commons Attribution (CC BY) license (http://creativecommons.org/licenses/by/4.0/). 